\title{
Do Corrupt Governments Receive Less Foreign Aid?
}

\section{Citation}

Alesina, Alberto, and Beatrice Weder. 2002. Do corrupt governments receive less foreign aid? American Economic Review 92(4): 1126-1137.

\section{Published Version}

doi:10.1257/00028280260344669

\section{Permanent link}

http://nrs.harvard.edu/urn-3:HUL.InstRepos:4553011

\section{Terms of Use}

This article was downloaded from Harvard University's DASH repository, and is made available under the terms and conditions applicable to Other Posted Material, as set forth at http:// nrs.harvard.edu/urn-3:HUL.InstRepos:dash.current.terms-of-use\#LAA

\section{Share Your Story}

The Harvard community has made this article openly available.

Please share how this access benefits you. Submit a story.

\section{Accessibility}




\title{
DO CORRUPT GOVERNMENTS RECEIVE LESS FOREIGN AID?
}

\author{
Alberto Alesina \\ Beatrice Weder \\ Working Paper 7108 \\ http://www.nber.org/papers/w7108 \\ NATIONAL BUREAU OF ECONOMIC RESEARCH \\ 1050 Massachusetts Avenue \\ Cambridge, MA 02138 \\ May 1999
}

We thank Giuseppe Iarossi and Pablo Zoido Lobaton for helping us with data, and Miguel Braun for excellent research assistance. Alesina is grateful to the Weatherhead Center for International Affairs of Harvard University for financial support. He also thanks the NSF for a grant through the NBER. Weder thanks the WWZ Foerderverein for a project grant. Part of this paper was written while she was a research fellow at the Center for Financial Studies in Frankfurt; she thanks the Center for their hospitality. The views expressed herein are those of the authors and do not necessarily reflect the views of the National Bureau of Economic Research.

1999 by Alberto Alesina and Beatrice Weder. All rights reserved. Short sections of text, not to exceed two paragraphs, may be quoted without explicit permission provided that full credit, including ${ }^{\mathbb{C}}$ notice, is given to the source. 
Do Corrupt Governments Receive Less Foreign Aid?

Alberto Alesina and Beatrice Weder

NBER Working Paper No. 7108

May 1999

\begin{abstract}
Critics of foreign aid programs argue that these funds often support corrupt governments and inefficient bureaucracies. Supporters argue that foreign aid can be used to reward good governments. This paper documents that there is no evidence that less corrupt governments receive more foreign aid. On the contrary, according to some measures of corruption, more corrupt governments receive more aid. Also, we could not find any evidence that an increase in foreign aid reduces corruption. In summary, the answer to the question posed in the title is "no."
\end{abstract}
Alberto Alesina
Department of Economics
Harvard University
Cambridge, MA 02138
and NBER
aalesina@harvard.edu

Beatrice Weder

University of Basel

Wirtschaftswissenschaftliches Zentrum

Abteilung Angewandte Wirtschaftsforschung

Petersgraben 51

4003 Basel

Switzerland

WEDER@ubaclu.unibas.ch 


\section{Introduction}

The differences in well-being across the world are staggering: income per capita in the U.S. is sixty times larger than in Ethiopia and about fifty times larger than in Mali.' Not surprisingly, there is a demand for foreign aid programs.

International programs to alleviate poverty include bilateral aid from richer to poorer countries, multilateral aid from international organizations, grants at below market rates, technical assistance and debt forgiveness programs, just to name a few. The rhetoric which accompanies these programs is that they serve the purpose not only of reducing poverty, but also of rewarding good policies and efficient and honest governments. Donor countries and international organizations argue that their aid policies are meant to be selective and favor reforming government. The World Bank, for instance, has recently discussed more often and more openly the issue of how to enhance "good governance", where the latter means, in particular, low levels of corruption of the bureaucracy and of the officials of the receiving countries. ${ }^{2}$ The critics of these programs argue instead that, contrary to the more or less sincere intentions of the donors, corrupt governments receive just as much aid as less corrupt ones. Furthermore, often financial assistance does not reach the really needy in the developing country, but, instead, is wasted in inefficient public consumption. ${ }^{3}$ Many critics make an even stronger argument, namely that not only are corrupt governments not discriminated against in the flow of international assistance, but in fact foreign aid fosters corruption by increasing the size of resources fought over by interest groups and factions. ${ }^{4} \mathrm{~A}$ related argument put forward by Casella and Eichengreen (1996) suggest that foreign aid may be counterproductive if it delays the adoption of stabilization policies and policy reforms.

\footnotetext{
' This figures already take into account difference in purchasing power. Data from the World Bank Development Indicators for 1995.

${ }^{2}$ See, for instance, World Bank (1997).

${ }^{3}$ See World Bank (1998) for an excellent assessment of the effect of foreign aid.

${ }^{4}$ This argument is spelled out more generally in Lane and Tornell $(1996,1999)$.
} 
Given the amount of press that this discussion has received, it is somewhat surprising that the relationship between foreign assistance and domestic corruption has not received more systematic attention. This is precisely the goal of this paper. In particular, we ask four questions: First, do less corrupt governments receive more aid? Second, do different donors differ in their willingness to discriminate against corrupt governments? Third, does foreign aid reduce or foster corruption? Fourth, do commercial private flows like FDI behave differently with respect to corruption with relative to official aid?

Regarding the first question, we find that there is no evidence that bilateral or multilateral aid goes disproportionally to less corrupt governments. In fact, if anything, we find the opposite: according to some measures of aid, more corrupt governments receive more foreign aid than less corrupt ones, after controlling for several other determinants of aid. On the second question, we uncover some interesting differences between donors. Scandinavian countries give more to less corrupt governments, while the U.S. appears to give more assistance to more corrupt governments, even though this donor favors democracies over dictatorships. Multilateral aid, namely aid from international organizations, seems to pay no attention to the level of corruption of the receiving country. Therefore, it would seem that the rhetoric on "good governance" does not influence aid flows from multilateral organizations. In fact we could not find any significant difference between multilateral aid and total bilateral aid in terms of their sensitivity to the level of corruption of the receiving countries.

On the third question we find some evidence that indeed FDI behave differently than official aid. Private flows seem to pay some attention to corruption, at least more than official aid.

The fourth question is by far the hardest to answer for several reasons. First of all, data on corruption not only are imperfect by their nature, but they also have been collected for large sample of countries only very recently. Therefore, it is quite difficult 
to measure changes in corruption levels to be associated with changes in received aid. Second, it is not quite clear what the determinants of corruption are, thus it is unclear what one should control for in evaluating the effect of aid on corruption. ${ }^{5}$ Given these two critical problems, results on this issue should be taken with extreme caution. In any case, we could not find any evidence that foreign aid reduces corruption.

This paper is at the crossroads of two strands of literature. One is the recent revival of work on the determinants and effects of foreign aid, summarized in World Bank (1998). The empirical work on aid has established three results: 1) foreign aid is most often used for largely wasteful public consumption [Boone (1994; 1996)]; 2) countries following good policies are helped by foreign assistance and aid, but the probability that a country adopts "good" policies is not influenced by the amount of foreign aid received [Burnside and Dollar (1997)]; and 3) donor countries disburse foreign aid largely as a function of strategic and geo-political considerations, rather than real needs of the receiving countries [Alesina and Dollar (1998)].

The second strand of the literature is the one on the measurement and consequences of corruption, and includes the empirical work by Mauro (1995), Knack and Keefer (1995), Borner, Brunetti and Weder (1995), Brunetti, Kisunko and Weder (1998a) and Johnson, Kaufmann and Zoido-Lobaton (1998). This empirical literature has made some progress in providing various measures of corruption for samples of many countries. The evidence points to the negative consequences of corruption on growth. ${ }^{6}$ Thus, if our results on foreign aid stand, they suggest that foreign aid may increase, or, at best, has no effect on corruption. It follows that foreign aid does not improve growth by improving the quality of government.

\footnotetext{
${ }^{5}$ For some work on the determinants of corruption in cross-country samples see Ades and DiTella (1997), Braun and DiTella (1999), Van Rijckeghem and Weder (1997).

${ }^{6}$ For general studies of corruption see e.g. Shleifer and Vishny (1993) and Tanzi (1994); a recent survey of the literature is provided in Bardan (1997).
} 
Needless to say, corruption is very difficult to measure. In this paper, rather than providing a new index or choosing one from the available list, we check our results using a large number of cross-country measures of corruption. While we would not trust 100 percent any specific measure of corruption, and thus any result based on such a specific measure, we feel relatively confident that if a certain pattern of results is consistent for every measure of corruption, then one can be more comfortable with the empirical finding.

This paper is organized as follows. Section 2 discusses the questions we are interested in. Section 3 presents our data. Section 4 discusses empirically whether the level of corruption in receiving countries influences the level of aid received. Section 5 briefly discusses FDI. Section 6 attempts to evaluate whether more aid received by a country fosters corruption. The last section concludes.

\section{Questions, Data and Methodology}

The first question we ask is very simple: do corrupt governments receive more or less multilateral and bilateral aid, after controlling for other determinants of aid flows?

Almost every analysis of foreign aid face an almost insurmountable problem of reverse causality. For instance, the fact that poorer countries receive more aid does not mean that aid causes poverty, but that donors target poor countries. The fact that countries with poorly developed institutions receive more aid (if they do) may mean that donors are trying to help build institutions, not that aid is bad for good governance.

This problem is less serious for corruption: it is hard to argue that aid should go to more corrupt countries to help reduce corruption. In fact, international organizations and bilateral donors have often made the opposite claim, namely that they should try to discriminate against corruption. Therefore, if one finds that more corrupt governments 
receive more foreign aid, one could safely interpret this finding as a serious failure in the decision process allocating aid amongst developing countries. An important caveat is, however, that measures of corruption are generally very correlated to many other characteristics of countries, like poverty and poor institutional development, which may be targeted by donors. Obviously, one may control for all of the above, (as we try to do) but these controls may not solve the problem completely.

The second question we ask is whether there is a difference between donors, namely whether multilateral donors such as international organizations pay more attention to corruption and/or whether there are significant differences amongst donor countries.

Aid policies of bilateral donors may be influenced by a host of factors which have very little to do with corruption. For instance, Alesina and Dollar (1998) show that colonial ties and political alliances are major determinants of bilateral aid flows, after controlling for many other factors. ${ }^{7}$ Thus, a donor country will give disproportionately to its former colonies regardless of their level of corruption. However, there might be significant differences amongst donor countries. The same authors document that Scandinavian countries target "well-deserving" recipients more than any of the other donors. Below we investigate if this is the case with reference to corruption. Since international organizations should be less directly affected by the colonial history of the recipients, international alliances and geopolitical considerations, one may expect that multilateral aid flows may be more responsive to the characteristics of policies and institutions of receiving countries. In other words, one may expect that multilateral aid should penalize corruption more than bilateral aid.

The third question is whether or not private flows and official aid react differently to measures of institutional development.

\footnotetext{
${ }^{7}$ For a discussion of previous empirical findings on this point, see Maizels and Nissanke (1984) and the literature reviewed in World Bank (1998)
} 
Given the proven negative effects of corruption on overall investment we would expect that foreign direct investment flow would be sensitive to high corruption. Most foreign direct investment is at least partially irreversible and should therefore be sensitive to uncertainties in high corruption environment. However, the relationship between private flows and corruption may be more complicated. For instance, if foreign investors become part of the circle of insiders that profit most from corrupt arrangements they will prefer such countries.. This is a similar argument as in the case of FDI and import substitution: to the extent that foreign direct investors can share in the profits of protected markets they will prefer countries that is have high import barriers and actively lobby in favor for their maintenance. This particular concern might be smaller in the case of short term and easily reversible private capital flows. On the other hand, by the same token, such flows would be less sensitive to corruption anyway.

The forth question is whether foreign aid increases or decreases corruption. Why this question is interesting is self-evident, particularly in light of the results which inversely relate corruption and institutional quality to economic growth.

In the United States, an influential argument often made is that both direct U.S. aid and indirect aid through multilateral organizations is counterproductive and therefore implies an unnecessary burden on the taxpayers. In the political rhetoric, often aid programs to poverty-stricken regions or countries are bunched up with criticism of "rescue packages" for crisis countries, like Mexico in 1994, or Brazil and Russia recently. Our focus is on foreign aid, so we have nothing to offer on the second issue.

\section{Data}

Corruption measures are available from various sources. Most of them are risk assessments by private companies which sell their expertise to multinational companies and investors. With the increasing interest in the developmental consequences of 
corruption, international agencies have also started to monitor corruption and have developed new measures. We use seven indicators of corruption from six different sources. All these indices are coded such that a higher number means less corruption.

The most frequently used measure of corruption in academic research is one compiled from the International Country Risk Guide (ICRG). This is the only measure which has yearly data since 1982 and covers the largest number of countries. Thus, our variable constructed using this index, CORRICRG, is defined as follows: A low score means that "high government officials are likely to demand special payments" and "illegal payments are generally expected throughout lower levels" in the form of "bribes connected with import and export licenses, exchange controls, tax assessment, policy protection, or loans". 8

Our second source of corruption data is a survey originally conducted for the World Development Report 1997, and which was subsequently expanded at the University of Basel. ${ }^{9}$ The data is derived from surveys of the private sector in 74 countries. We use two indicators of corruption from this source. The first indicator CORRWDR 1 is based on a question of how frequently firms have to pay bribes in order to do business. The second indicator CORRWDR2 is based on a question which asked entrepreneurs to rate comparatively the importance of different obstacles to doing business. The correlation between the first and the third indicator is not perfect since a high level of corruption does not necessarily mean that this is also a major problem for investors. Many observers have commented that not all forms of corruption are equally harmful. ${ }^{10}$ Some commentators go as far as suggesting that some form of bribery system may increase efficiency in the bureaucracy.

\footnotetext{
${ }^{8}$ See Knack and Keefer (1995).

9 See Brunetti, Kisunko and Weder (1998b) for a detailed description of the data. The data set is available on the net at www.unibas.ch/wwz/wifor/survey/

${ }^{10}$ See e.g. Shleifer and Vishny (1997)
} 
The third source of corruption data is from Standard and Poors. The variable CORRSAP reflects "losses and costs" to firms due to corruption. ${ }^{11}$.

The fourth source is Business International (incorporated into the Economist Intelligence Unit) and first used in Mauro (1995). This is the oldest data we consider, it is an average of the rating from 1980-1983. The indicator reflects experts assessments on: "The degree to which business transactions involve corruption or questionable payments".

The fifth source of corruption data is the World Competitiveness Yearbook by the Institute for Management Development (IMD) in Geneva. It includes a measure of "improper practices such as bribing and corruption".

Finally, Transparency International, a non-profit organization dedicated to combating corruption has provided a summary indicator of corruption. CORRTI is based on a poll of polls, that is the scores of 5 to 10 surveys, depending on the country, were aggregated into an summary indicator of corruption. This summary index was first calculated in 1996 and became widely cited in the press. It was also often criticized because it initially included surveys of very different quality. For the 1998 indicator the methodology was revised and the summary indicator was improved. ${ }^{12}$

All these indices and their sources are listed in Table 1 together with all the other variables which we use in this paper. Even though each of the seven indicators gets at the phenomena of corruption from a slightly different angle, they are highly correlated as shown by the correlation matrix in Table 2 . Of the 28 cross correlations, 22 are above $0.5 ; 18$ are above 0.6 , and 10 are above 0.7 . These relatively high correlations provide some confidence in the measures of corruption since most of them were compiled by different institutions using very different experts and survey methodologies.

$"$ We thank Daniel Kaufmann for sharing this data with us. 
Our objective is to test whether foreign aid is allocated to countries with less corruption. We estimate the effect of corruption on foreign aid controlling for other determinants of the allocation of foreign aid such as the level of income of recipient countries, their size, economic policies, political system and historic or political links with donors. In our choice of control variables we largely follow Alesina and Dollar (1998). These variables include: a) colonial history of the receiving country; b) a proxy for political alliance, constructed using the frequency of cases in which the receiving country has voted in the United Nations in the same way as the donor; c) measures of policies and economic conditions of the receiving countries, such as a measure of openness and, of course, per capita income; and, d) measures of institutional development of the receiving country. The detailed description and sources of control variables are given in Table 1.

A few comments on these controls are appropriate. First, UN votes are often considered fairly irrelevant, from the point of view of international politics. However, patterns of UN votes are probably highly correlated with patterns of alliances and commonality of interests. There is actually a fairly high dispersion in vote patterns even amongst Western democracies and their allies. The traditional East/West cutting line was not the only relevant cleavage in UN votes. Second, it is not a priori clear whether a receiving country "buys" foreign aid by its voting pattern in the UN or whether foreign aid "rewards" past votes. This is an issue which we do not explore here. ${ }^{13}$

Our measure of openness is taken from Sachs and Warner (1995). This index has been criticized as a "black box"14 which includes many indicators of "good" versus "bad"

\footnotetext{
${ }^{12}$ The 1998 indicator is actually includes the assessment of the previous three years also. Detailed descriptions and the indicators can be viewed at http:/www.transparency.de/documents/cpi/

${ }^{13}$ For a more extensive discussion of this point see Alesina and Dollar (1998)

${ }^{14} \mathrm{~A}$ country is classified as closed if at least one of the five following criteria apply: (i) non tariff barriers cover $40 \%$ or more of trade, (ii) average tariff rates are $40 \%$ or more, (iii) the black market exchange rate is depreciated by $20 \%$ or more relative to the official exchange rate, (iv) the country has a socialist economic system, (v) the state holds a monopoly on major exports.
} 
policies which have little to do with openness per se. ${ }^{15}$ However for our purposes this summary indicator seems appropriate, because we are not especially interested in openness, per se, but more in an indicator of "policy stance". In fact, this index is better for us than a simple measure of trade openness like export over GDP for instance, because donors should target good policies in general rather than openness strictly defined.

Finally, measures of institutional development (namely whether the receiving country is a democracy or not) are used since international organizations and donors may discriminate against certain types of non-democratic governments. This point is emphasized and analyzed in detail in Alesina and Dollar (1998).

\section{Aid and Corruption}

\subsection{Total Aid}

We begin with a measure of total multilateral and bilateral aid received by developing countries. First of all we need to decide how to "scale" the total amount of foreign aid received by a country. Standard scaling procedures are aid over GDP or per capital aid (aid over population). A third possibility which is of interest for a discussion of corruption is aid over government spending. The last one captures how much of the public resources are received for free, rather than raised domestically or with commercial international loans. This measure may be the closest in spirit to the "Voracity Effect" discussed by Lane and Tornell $(1996,1999)$. The idea is that when a windfall of public resources is obtained in a community then lobbying, redistributive conflicts and corruption may turn that windfall into a social loss. In any case, we will present results using all three measures of aid. As we shall see, results are sometimes different in interesting manners.

\footnotetext{
${ }^{15}$ For a particularly pointed criticism, see Rodriguez and Rodrik (1999).
} 
We begin with some impressionistic figures. Figures 1, 2 and 3 plot a measure of corruption, ICRG, on the vertical axis and official development assistance from OECD countries in per capita terms as a share of GDP and as a share of government spending. All of the three picture essentially show a cloud with virtually no pattern. Remember that because of the way this corruption index is constructed, a higher number means less corruption, therefore an upward sloping line would indicate that less corrupted countries receive more aid. There is no indication of an upward sloping line in any of the three pictures.

Table 3 has six columns, two for each definition of aid and uses the ICRG measure of corruption. The first column of each pair includes a "minimalist" regression with only a measure of per capita income, of population and an indicator variable for Israel. In fact, it is well known that because of political reasons linked to the Middle East conflict, this country receives a large amount of aid, especially from the U.S and in per capita terms. ${ }^{16}$ The second column includes our richer specification. We use two specifications because the first one can be run on more countries, and the problem of degrees of freedom is important for some of the measures of corruption, discussed below.

Remember that a negative sign on the corruption variable implies that more corrupt governments receive more foreign aid. In all six of the regressions, the coefficient is indeed negative, although it is statistically significant only in the two regressions for aid over government spending and in one of aid/GDP. These results immediately suggest two observations. The first one is that there is no evidence whatsoever that more corrupt governments are discriminated by foreign donors. The second is that if one looks at $\mathrm{Aid} / \mathrm{GOV}$, in fact there is some evidence that more corrupt governments receive more. The difference between aid/GOV and Aid/per capita is

\footnotetext{
${ }^{16}$ In any specification without an indicator variable for Israel, the latter would appear as a large outlier, particularly in the regressions where the right hand side is aid per capita.
} 
suggestive. One manifestation of corruption is may be a high tax evasion, (perhaps unreported bribes substitute for reported taxes), a large black economy and more generally lack of capacity or willingness of the government to collect "official" revenues. Thus, high corruption, may imply that domestically raised public resources are low and a higher fraction of public resources are covered by foreign aid. The values of the coefficients in the first two column imply that, ceteris paribus, a country that is more corrupt by one standard deviation from the mean, receives about 9 percentage points of aid over government expenditures.

Table 4 checks the robustness of the results by considering other measures of corruption. The table reports the $t$ statistic on the corruption variable and the number of observations for the six regressions of Table 3 . In other words, we changed the corruption variable in the regressions of Table 3, and in Table 4 reported, for brevity, only the results of the corruption variable. ${ }^{17}$ Note that the number of observations vary widely because of the availability of the corruption index.

Of the 42 coefficients 39 are negative and, of those, 17 are significant at standard confidence levels, that is 10 per cent or better. (Remember that a negative coefficient implies more aid to more corrupt governments). Only the remaining 3 are positive, but they are statistically insignificant. Looking at the pattern of coefficients, we confirm the result of the previous table, namely that the positive effect of higher corruption on aid is stronger if aid is scaled by government spending of the receiving country.

In summary this sections shows that being less corrupt does not help with donors; if anything it hurts!

\subsection{Individual Donors}

\footnotetext{
${ }^{17}$ Complete results are available upon request.
} 
In this section we explore whether one can find significant differences in the behavior of individual donors. Table 5 can be read as follows. We have run a TOBIT regression in which the left-hand side is the amount of aid/per capita given by each individual donor. We use the TOBIT procedures since there are several "zeros", namely some donors do not give to all receiving countries. ${ }^{18}$ The controls are listed for every regression and they are slightly different for every regressions. For instance, certain donors do not have colonies and the indicator variable for Israel is relevant only for the US. ${ }^{19}$

This table shows interesting cross country differences. Scandinavian countries (plus Australia) seem to give more to less corrupt governments. The fact that Scandinavia seems to allocated its aid "well" is consistent with the results of Alesina and Dollar $(1998)^{20}$. At the opposite extreme is the US, for which the significant negative coefficient on the corruption variable indicates that more US foreign aid goes to more corrupt. countries. Interestingly the political rights variable indicates that the US give relatively more to democratic countries. A similar finding is reported by Alesina and Dollar (1998) and these results, viewed together, suggest that the US may be more interested in democratic institutions per se relative to the quality of government. The coefficient in the regression of bilateral US aid shows that a country that is more corrupt (one standard deviation from the mean) receives about 8 US dollars more aid per capita.

Table 6 is the analog of Table 5 except that we now have aid/government rather than per capita aid. The results are similar to table 5. Once again the US and Scandinavia are on opposite extremes of the spectrum. Figure 4 gives a picture of the relationship between US aid and corruption. This figure plots the residuals of the US aid regression

\footnotetext{
${ }^{18}$ It is worth noting that, actually, the number of "zeros" is not very large. Most donors give to many receiving countries.

${ }^{19}$ Following Alesina and Dollar (1998) we also added an indicator variable for Egypt. Our results are unaffected regardless of whether or not this variable is included.

${ }^{20}$ Note that Scandinavian countries had no colonies
} 
form Table 6 without the corruption variable against the latter. One can easily see a downward relationship.

We have also estimated donor by donor regressions using other measures of corruption. Given the relatively few number of observations in several of these, due to the observation lost because of data availability plus the "zeros" we do not show them, but they are available upon request.

Finally we have explored whether there are systematic differences between multilateral and bilateral donors. As mentioned above, a priori, one might expect that multilateral donors would be less subject to political pressures and more prone to give to the more deserving, i.e. less corrupt countries. Estimates using the ICRG corruption show that multilateral aid is positively correlated with corruption (using specifications (1) and (5) in Table 3) while bilateral aid is negatively correlated with corruption. But both coefficients are not significant at conventional levels and also this result is not robust to changes in the measurement of the corruption indicator. ${ }^{21}$ Therefore, we conclude that there are no large differences between multilateral organizations and bilateral donors allocate aid. Neither seem to have targeted countries with little corruption.

\section{Foreign Direct Investment and Private Capital Flows}

In this brief section we investigate whether private flows respond differently to corruption relative to official assistance. Wei (1997) argues that more corrupt countries, ceteris paribus, receive less FDI. He uses FDI data from 7 or 8 industrialized countries to a sample of about 40 countries, most of which are not poor developing countries. If we

\footnotetext{
${ }^{21}$ All these results are available upon request
} 
cross Wei's data on developing countries with the measures of corruption we are left with too few degrees of freedom for a meaningful analysis. ${ }^{22}$

Table 7 reports our results on a few regressions on FDI, FDI and portfolio flows and total private capital flows all over GDP of the receiving country. The precise definition of all the three variables is given in Table 1. FDI is the most narrow measure of private capital flows and is related to longer term investment that have certain qualities of irreversibility. Therefore it is conceivable that FDI investors would be most sensitive to corruption. The counter-argument, is that a foreign direct investor can factually become a local entrepreneur and may be able to share in the profits of certain forms of corruption. Such instances would mitigate the negative reaction of FDI flows to corruption. The broader measures of private capital inflows, (including portfolio investments and bank loans into developing countries) are less susceptible to this particular problem since they tend to be more easily reversible and of a shorter maturity. But, for this same reason they may also not react very strongly to corruption. Our results on private capital flows confirm this suspicion, they document that private capital flows react negatively to higher corruption but that this relationship is not very strong.

We present estimates for three specifications. The first one is the minimalist specification that ensures comparability with the aid results and includes only income and population. Looking at a plot of FDI it is clear that Singapore is a big outlier with a very large amount of FDI over GDP. According to all indices Singapore has a very low level of corruption. Regressions which do not eliminate this outlier would generate the impression that FDI react negatively to corruption than they actually do, because the result would be unduly driven by one country. Therefore in the second regression we include an indicator variable for Singapore. Finally we present an extended specification that includes a measure of openness, on the political system democracy and land area, a measure of market size. We conducted a wide search for specification for the estimates

\footnotetext{
${ }^{22}$ Although in the end we ended up not using them, we still want to acknowledge Wei's kindness in providing us with his data
} 
of private capital flows. Surprisingly many of the reasonable determinants of FDI and other private capital flows (included variables of human capital, measures the depth of the Financial system, measures political instability, black market premium, ethnolinguistic fractionalization, oil exporting countries, inflation and M2/GDP) were not significant.

If one compares the results of Table 7 with those of Table 3 one notes differences. All the coefficients in Tale 7 are positive, even though none is significant at standard confidence level. ${ }^{23}$ Table 8 is organized as Table 4 , namely it reports only the $t$ statistic on different corruption measures and the number of observations on the regressions of Table 7. Once again, a comparison between Tables 8 and 4 reveal striking differences. In table 8 out of 42 coefficients, 30 are positive. Amongst the latter 8 are significatively positive at standard level of significance. Several others have a $t$ statistic above 1.5. The point we want to push is not that there is a strong evidence that FDI react very strongly against corruption (even though according to at least one measure of corruption, they do) but rather that there are non trivial differences between the behavior of FDI and foreign aid. A comparison of Table 4 and 8 is generally supportive of this claim.

\section{Dynamic effects of aid on corruption}

In order to measure the effects of aid on changes in corruption one would need a long time series on corruption measures. Even if those were available, they would probably not capture well small changes in corruption, given the nature of this variable. Thus any attempt to answer this question has to be taken very cautiously.

In Table 9 and 10 we look at simple statistic linking aid received in the previous period and the amount of corruption reported in a country. This exercise could only be conducted with the ICRG corruption indicator because it is the only one that has time

\footnotetext{
${ }^{23}$ Note that some of these coefficients would become significant if we left out the indicator variable for Singapore.
} 
series data. Table 9 focuses on 5 years periods, Table 10 on a longer horizon. Both tables show no evidence that aid received in previous period goes to country that are less corrupt later on. The bold entry show cases of the reverse: namely more aid going to countries that later on are more corrupt. Most of the entries are bold, even though the differences are not statistically significant. In all groups the variance is very large, therefore out of the 31 bold pairs only in 2 cases the differences are statistically significant.

A additional problem in pursuing this analysis is that measures of corruption show relatively small amounts of within country variations. In fact, the level of corruption may often take generations to significatively change. We have also examined case by case examples of large changes (up of down) of the corruption index and tried to relate them to previous changes in foreign aid received. We did not uncover any consistent pattern across countries. We also did not uncover signs of an increase in aid following a reduction in the amount of measured corruption, but again data limitations have to be kept in mind.

\section{Conclusions}

There are two ways of summarizing the evidence presented in this paper. A minimalist summary would simply be that the answer to the question posed in the title is a loud no. There is no evidence whatsoever that less corrupt countries receive more foreign aid. This conclusion adds another piece of evidence to the view (consistent with some previous literature) that foreign aid programs are often unsuccessful because they are not well targeted. This "minimalist" and negative conclusion is very "robust" in the sense in our vast exploration of the data we never found any even small or weak evidence of a negative effect of corruption on aid. 
Beyond this result, the data are not so clear cut, but they still allow us to say some more. For instance, it would appear that at least according to most measures, corrupt governments actually receive more foreign aid rather than less, particularly if aid is scaled by the size of the public sector of the receiving country. Also we found significant differences across donor. Consistently with evidence on other variables Scandinavian donors (the most generous in per capita terms) do reward less corrupt receivers. On the other hand the US appear to favor democracies, but seems to pay no attention whatsoever to quality of government of receiving countries. We find some evidence that private flows, as opposed to official flows, do a batter job at discriminating against more corrupt governments. Finally, we find weak indication of a "voracity effect" of foreign aid, meaning that countries that receive more aid have tend to have higher corruption. 


\section{References}

Ades, Alberto and Rafael Di Tella (1995) "Competition and Corruption" mimeograph, Keble College, Oxford University, mimeo.

Alesina, Alberto and David Dollar (1998) "Who gives foreign aid to whom and why?", NBER Working Paper No. 6612

Bardhan, Pranab (1997) "Corruption and Development: A Review of Issues," Journal of Economic Literature, V. 35

Boone, Peter (1994) "The Impact of Foreign Aid on Savings and Growth", London School of Economics, mimeo

Boone, Peter (1996) "Politics and the Effectiveness of Foreign Aid", European Economic Review 40:289-329

Burnside C. and David Dollar (1997) "Aid, Policies and Growth", World Bank Policy Research Paper No. 1777

Braun Miguel. and Rafael Di Tella (1999) "Inflation and Corruption" unpublished

Borner Silvio, Aymo Brunetti and Beatrice Weder (1995) Political Credibility and Economic Growth, London: McMillan

Brunetti Aymo, Gregory Kisunko and Beatrice Weder (1998a) "Credibility of Rules and Economic Growth: Evidence from a Worldwide Survey of the Private Sector" (1997b), World Bank Economic Review 12 (3), pp. 353-384

Brunetti Aymo, Gregory Kisunko and Beatrice Weder (1998b) " How Firms in 72 Countries Rate Their Institutional Environment", WWZ Discussion Paper No. 9811, Basel

Casella Alessandra, and Barry Eichengreen (1996) "Can Foreign Aid Accelerate Stabilisation?, Economic-Journal, 106, pp. 605-19

Frey, Bruno and Friedrich Schneider (1986) "Competing Models of International Lending Activities", Journal of Development Economics, pp. 225-45

Klitgaard, Robert (1988), Controlling Corruption, Berkeley: University of California Press 
Knack, Stephen and Philip Keefer (1995) "Institutions and Economic Performance:

Cross-Country Tests Using Alternative Institutional Measures ", Economics and Politics 7, pp. 207-227.

Lane Philip, and A.aron Tornell (1996) "Power Growth and the Voracity Effect", Journal of Economic Growth, pp. 213-41

Lane Philip and Aaron Tornell (1999) : "The Voracity Effect" American Economic Review, March pp. 22-46.

Johnson, Simon, Daniel Kaufmann and Pablo Zoido-Lobaton (1998) "Regulatory Discretion and the Unofficial Economy", American Economic Review Papers and Proceedings 88, 2 pp. 387-392.

Maizels A and Machiko Nissanke (1984) "Motivations for Aid to Developing Countries" World Development, 12(9), pp. 879-900

Mauro, Paolo (1995) "Corruption and Growth", Quarterly Journal of Economics 110 , pp. 681-712.

Rodriguez, Francisco and Dani. Rodrik (1999) "Trade Policy and Economic Growth: A Skeptic's Guide to Cross-National Evidence", NBER Working Paper No. 7081

Sachs, Jeffrey and Andrew Warner (1995) "Economic Reform and the Process of Global Intergration", Brookings Papers on Economic Activity 1, pp. 1-118.

Shleifer, Andrei and Robert Vishny, (1993) "Corruption", Quarterly Journal of Economics, pp. 599-617.

Tanzi, Vito (1994) "Corruption, Governmental Activities, and Markets", IMF Working Paper No. 94/99 (1994).

Van Rijckeghem, Caroline and Beatrice Weder (1997) "Corruption and the Rate of Temptation: Do Low Wages in the Civil Service Cause Corruption?", IMF Working Paper No. $97 / 73$

Wei, Shang-Jin (1997) "How Taxing is Corruption on International Investors?" NBER Working Paper No. 6030. 
The World Bank (1997): The State in a Changing World, World Development Report 1997, The World Bank and Oxford University Press

The World Bank (1988): Assessing Aid: What Works, What Doesn't, and Why, The World Bank and Oxford University Press 
Table 1: Description of Data and Sources

\begin{tabular}{|c|c|c|}
\hline VARIABLE & Description & Source \\
\hline AID PER CAPITA & $\begin{array}{l}\text { Official development assistance (constant } 87 \$ \text { ), } \\
\text { average } 1975-1995\end{array}$ & $\begin{array}{l}\text { The World Bank, World } \\
\text { Development Indicators }\end{array}$ \\
\hline AID/GDP & $\begin{array}{l}\text { Official development assistance as a share of GNP, } \\
\text { average } 1975-1995\end{array}$ & $\begin{array}{l}\text { The World Bank, World } \\
\text { Development Indicators }\end{array}$ \\
\hline AID/GOV & $\begin{array}{l}\text { Official development assistance in percent of } \\
\text { government expenditures, average 1975-1995 }\end{array}$ & $\begin{array}{l}\text { The World Bank, World } \\
\text { Development Indicators }\end{array}$ \\
\hline $\begin{array}{l}\text { BILATERAL AID } \\
\text { PER CAPITA }\end{array}$ & OECD's bilateral aid, net per capita (constant $85 \$$ ) & $\begin{array}{l}\text { Alesina and Dollar } \\
(1998), \text { OECD }\end{array}$ \\
\hline COLSXXX & $\begin{array}{l}\text { Number of years as a Colony of country xxx } \\
\text { Since } 1900\end{array}$ & $\begin{array}{l}\text { Alesina and Dollar } \\
(1998), \text { CIA (1996) }\end{array}$ \\
\hline CORRBI & $\begin{array}{l}\text { Bl corruption indicator average } 1980-1993 \text {, collected } \\
\text { by Mauro (1995), } \\
10 \text { (lowest corruption) } 0 \text { (highest corruption) }\end{array}$ & $\begin{array}{l}\text { Bl, now Economist } \\
\text { Intelligence Unit }\end{array}$ \\
\hline CORRICRG & $\begin{array}{l}\text { Corruption index from ICRG, annual surveys from } 1982- \\
1995 \\
6 \text { (lowest corruption) } 0 \text { (highest corruption) }\end{array}$ & $\begin{array}{l}\text { International County Risk } \\
\text { Guide (1996), } \\
\text { Knack and Keefer (1995) }\end{array}$ \\
\hline CORRIMD & $\begin{array}{l}\text { Corruption index from World Competitiveness } \\
\text { Yearbook, } 1996 \text {, original name: improper practices such } \\
\text { as bribing and corruption } \\
10 \text { (lowest corruption) } 0 \text { (highest corruption) }\end{array}$ & $\begin{array}{l}\text { Institute for Management } \\
\text { Development, IMD }\end{array}$ \\
\hline CORRSAP & $\begin{array}{l}\text { Losses and costs of corruption, from Standard and } \\
\text { Poors 1997, redefined to: } \\
10 \text { (lowest corruption) } 0 \text { (highest corruption) }\end{array}$ & Standard and Poors \\
\hline CORRTI & $\begin{array}{l}\text { Corruption index from Transparency International, } \\
\text { survey } 1997 \\
10 \text { (lowest corruption) } 1 \text { (highest corruption) }\end{array}$ & $\begin{array}{l}\text { Transpanrecy } \\
\text { International }\end{array}$ \\
\hline CORRWDR1 & $\begin{array}{l}\text { Level of corruption index, from survey of World } \\
\text { Development Report } 1997 \text {, plus } 5 \text { additional surveys } \\
6 \text { (lowest corruption) } 1 \text { (highest corruption) }\end{array}$ & $\begin{array}{l}\text { Brunetti, Kisunko and } \\
\text { Weder (1998b) }\end{array}$ \\
\hline CORRWDR2 & $\begin{array}{l}\text { Corruption as a business obstacle, from survey of } \\
\text { World Development Report 1997, plus } 5 \text { additional } \\
\text { surveys } \\
6 \text { (lowest corruption) } 1 \text { (highest corruption) }\end{array}$ & $\begin{array}{l}\text { Brunetti, Kisunko and } \\
\text { Weder (1998b) }\end{array}$ \\
\hline DEMOCRACY & $\begin{array}{l}\text { Political Rights, recoded as } \\
\text { (7) democratic (1) autocratic government, } \\
\text { average } 1974-1989\end{array}$ & Gastil (1990) \\
\hline FDI & Net inflows of FDI (\% gdp), average 1975-1995 & $\begin{array}{l}\text { The World Bank, World } \\
\text { Development Indicators }\end{array}$ \\
\hline FDI+P. FLOWS & $\begin{array}{l}\text { Net direct and portfolio investment (comprises direct } \\
\text { investment in equity capital, reinvested earnings, and }\end{array}$ & $\begin{array}{l}\text { The World Bank, World } \\
\text { Development Indicators }\end{array}$ \\
\hline
\end{tabular}


other capital associated with intercompany transactions and transactions with nonresidents in financial securities (\% gdp), average 1975-1995

FRDXXX

INCOME

OPENNESS

PRIV. CAP. FLOWS

YEARS AS A COLONY
Percentage of times in which the recipient has voted in the UN as XXX

Real GDP per capita, beginning of period

Proportion of years in which the country is open

Net private capital flows consist of private debt and nondebt flows. Private debt flows include commercial bank lending, bonds, and other private credits; nondebt private flows are foreign direct investment and portfolio equity investment (\% gdp), average 1975-1995

Number of years as colony of any

Colonizer since 1900
Alesina and Dollar (1998),

Pen World Tables

Sachs and Warner (1995)

The World Bank, World

Development Indicators 


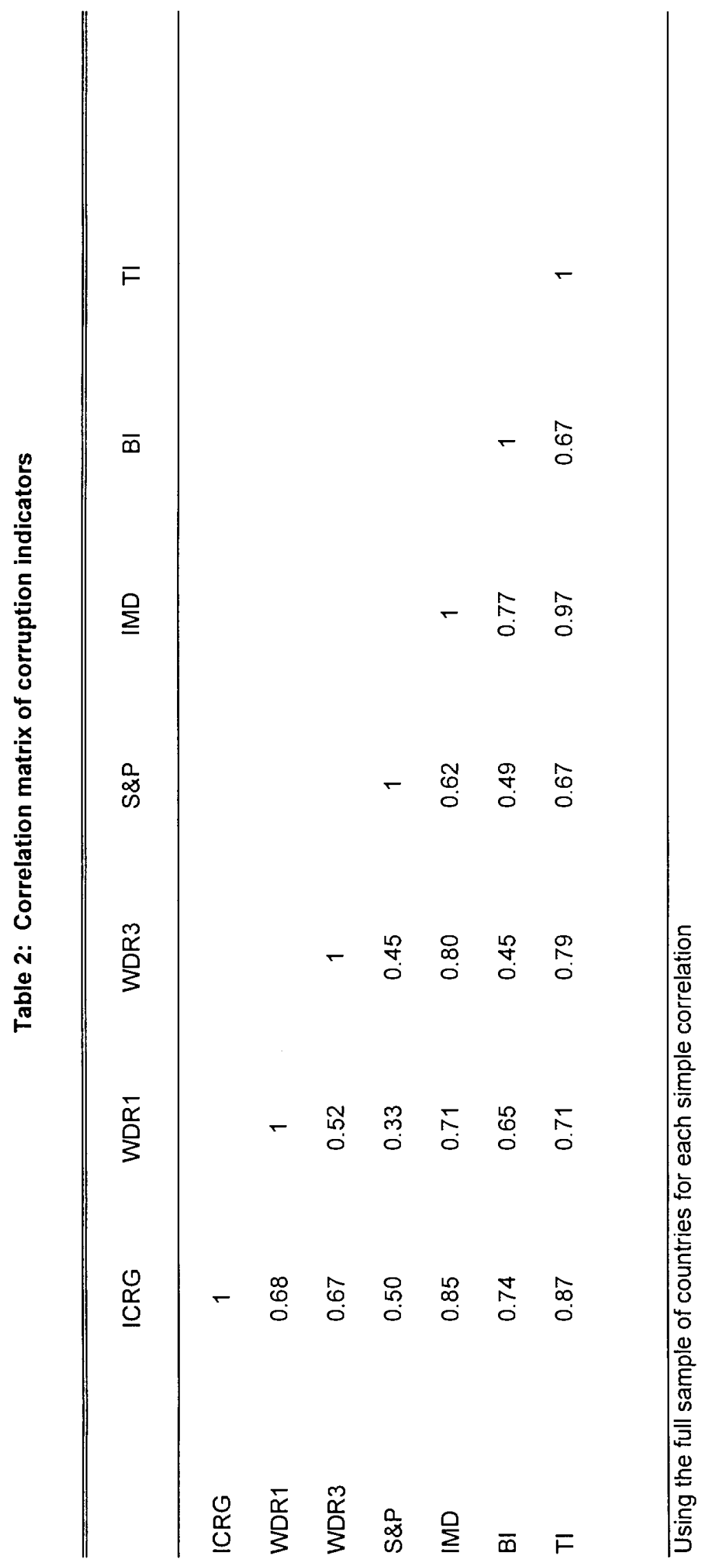


Table 3: Official foreign aid and corruption

\begin{tabular}{|c|c|c|c|c|c|c|}
\hline & \multicolumn{5}{|c|}{ Dependent Variable: Log } & \multirow[b]{2}{*}{$\begin{array}{c}\text { Aid } \\
\text { per cap. }\end{array}$} \\
\hline & $\begin{array}{l}\text { Aid/ } \\
\text { Gov }\end{array}$ & $\begin{array}{l}\text { Aid/ } \\
\text { Gov }\end{array}$ & $\begin{array}{l}\text { Aid/ } \\
\text { GNP }\end{array}$ & $\begin{array}{l}\text { Aid/ } \\
\text { GNP }\end{array}$ & $\begin{array}{c}\text { Aid } \\
\text { per cap. }\end{array}$ & \\
\hline Constant & $\begin{array}{l}22.95 \\
(9.66)\end{array}$ & $\begin{array}{l}-17.12 \\
(-1.05)\end{array}$ & $\begin{array}{c}25.35 \\
(13.02)\end{array}$ & $\begin{array}{l}-21.50 \\
(-1.40)\end{array}$ & $\begin{array}{c}17.82 \\
(13.03)\end{array}$ & $\begin{array}{l}-14.23 \\
(-1.33)\end{array}$ \\
\hline Log (initial income) & $\begin{array}{c}-1.74 \\
(-8.10)\end{array}$ & $\begin{array}{c}7.10 \\
(2.52)\end{array}$ & $\begin{array}{c}-1.93 \\
(-11.07)\end{array}$ & $\begin{array}{c}8.30 \\
(3.07)\end{array}$ & $\begin{array}{l}-0.69 \\
(-5.61)\end{array}$ & $\begin{array}{c}7.16 \\
(3.80)\end{array}$ \\
\hline Log (population) & $\begin{array}{c}-0.44 \\
(-4.46)\end{array}$ & $\begin{array}{c}2.08 \\
(1.29)\end{array}$ & $\begin{array}{l}-0.60 \\
(-7.39)\end{array}$ & $\begin{array}{c}1.13 \\
(0.73)\end{array}$ & $\begin{array}{c}-0.61 \\
(-10.65)\end{array}$ & $\begin{array}{c}0.44 \\
(0.40)\end{array}$ \\
\hline Israel & $\begin{array}{c}2.47 \\
(1.84)\end{array}$ & $\begin{array}{c}2.10 \\
(1.12)\end{array}$ & $\begin{array}{c}2.64 \\
(2.26)\end{array}$ & $\begin{array}{c}3.51 \\
(1.86)\end{array}$ & $\begin{array}{c}3.33 \\
(4.02)\end{array}$ & $\begin{array}{l}3.36 \\
(2.64)\end{array}$ \\
\hline Openness & & $\begin{array}{c}-0.52 \\
(-1.09)\end{array}$ & & $\begin{array}{c}-0.65 \\
(-1.37)\end{array}$ & & $\begin{array}{c}0.05 \\
(0.14)\end{array}$ \\
\hline Political Rights & & $\begin{array}{c}0.17 \\
(1.76)\end{array}$ & & $\begin{array}{c}0.06 \\
(0.67)\end{array}$ & & $\begin{array}{c}0.03 \\
(0.44)\end{array}$ \\
\hline Years as a colony & & $\begin{array}{l}-0.006 \\
(-0.95)\end{array}$ & & $\begin{array}{l}0.085 \\
(0.66)\end{array}$ & & $\begin{array}{l}0.001 \\
(0.21)\end{array}$ \\
\hline Friend of USA & & $\begin{array}{l}-0.008 \\
(-0.34)\end{array}$ & & $\begin{array}{c}-0.02 \\
(-0.86)\end{array}$ & & $\begin{array}{l}-0.002 \\
(-0.15)\end{array}$ \\
\hline Friend of Japan & & $\begin{array}{c}-0.11 \\
(-2.02)\end{array}$ & & $\begin{array}{c}-0.05 \\
(-0.88)\end{array}$ & & $\begin{array}{c}-0.05 \\
(-1.53)\end{array}$ \\
\hline $\log$ (initial income) $^{2}$ & & $\begin{array}{c}-0.61 \\
(-3.18)\end{array}$ & & $\begin{array}{c}-0.69 \\
(-3.74)\end{array}$ & & $\begin{array}{c}-0.53 \\
(-4.15)\end{array}$ \\
\hline $\log$ (population) 2 & & $\begin{array}{c}-0.08 \\
(-1.67)\end{array}$ & & $\begin{array}{c}-0.05 \\
(-1.11)\end{array}$ & & $\begin{array}{c}-0.03 \\
(-0.98)\end{array}$ \\
\hline $\begin{array}{l}\text { Corruption } \\
\text { ICRG }\end{array}$ & $\begin{array}{c}-0.36 \\
(-2.29)\end{array}$ & $\begin{array}{c}-0.39 \\
(-2.73)\end{array}$ & $\begin{array}{l}-0.25 \\
(-2.02)\end{array}$ & $\begin{array}{c}-0.13 \\
(-0.99)\end{array}$ & $\begin{array}{l}-0.06 \\
(-0.75)\end{array}$ & $\begin{array}{c}-0.05 \\
(-0.51)\end{array}$ \\
\hline $\begin{array}{l}\text { Adj. R2 } \\
\text { Number of obs. }\end{array}$ & $\begin{array}{c}0.56 \\
74\end{array}$ & $\begin{array}{c}0.72 \\
63 \\
\end{array}$ & $\begin{array}{c}0.68 \\
84 \\
\end{array}$ & $\begin{array}{c}0.74 \\
69 \\
\end{array}$ & $\begin{array}{c}0.62 \\
86 \\
\end{array}$ & $\begin{array}{c}0.72 \\
70 \\
\end{array}$ \\
\hline
\end{tabular}

T Statistics in Parentheses 


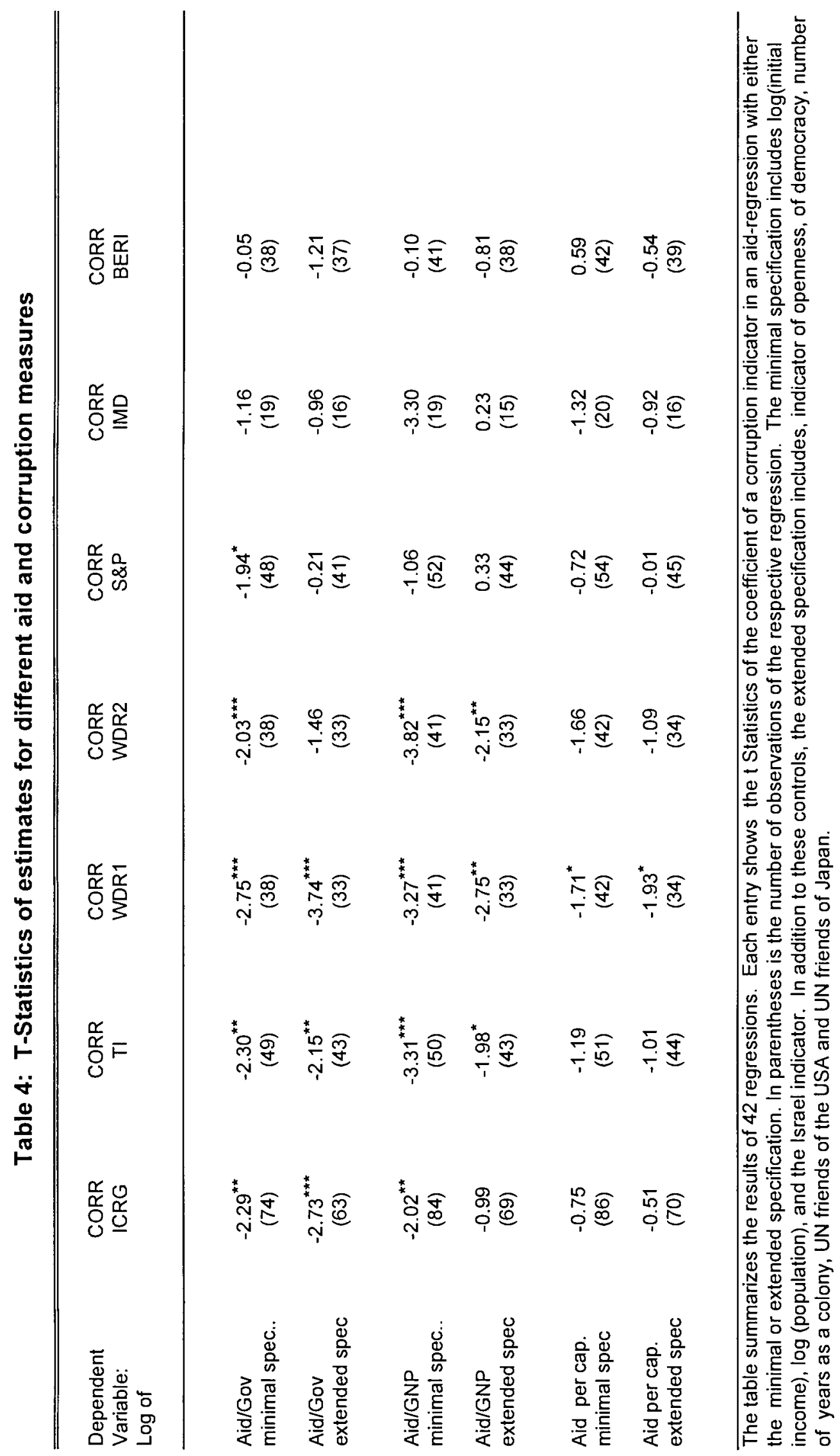




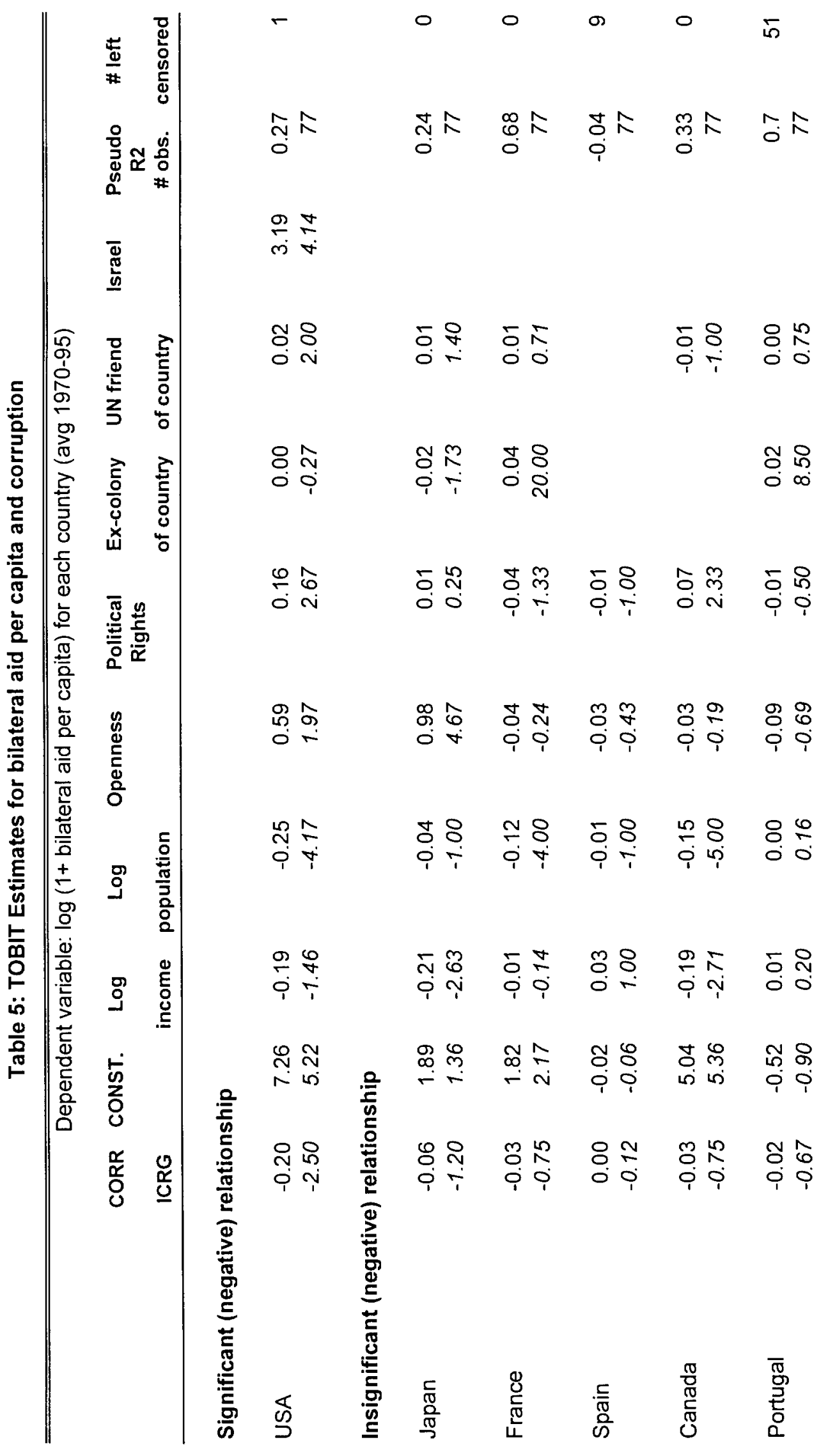




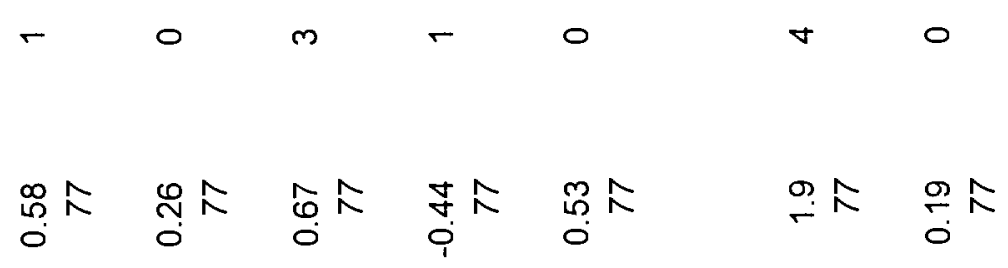

8 웅

8
8
0
0

$8 \stackrel{\circ}{\circ}$

$8 \underset{0}{8}$

m

ช 8
0
0
0

$5 \stackrel{8}{\circ}$

$\infty$
28
0
0

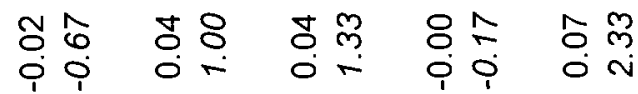

용

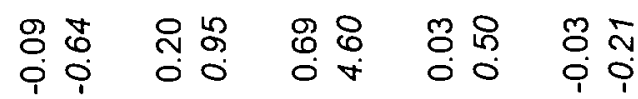

\begin{tabular}{ccc}
\multirow{2}{*}{$\infty$} \\
0 \\
0
\end{tabular}

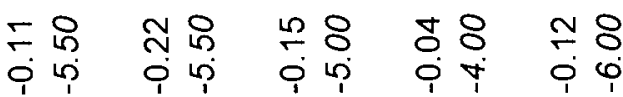

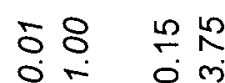

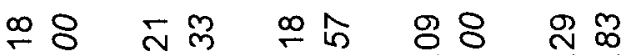

8898 ঢั

पूल

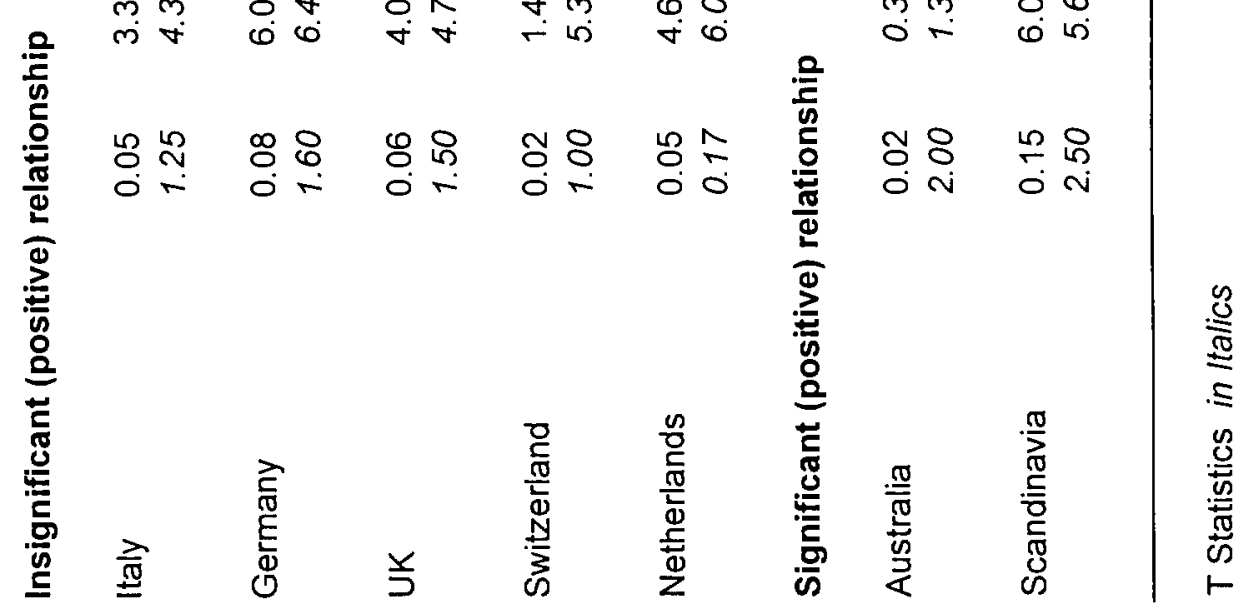




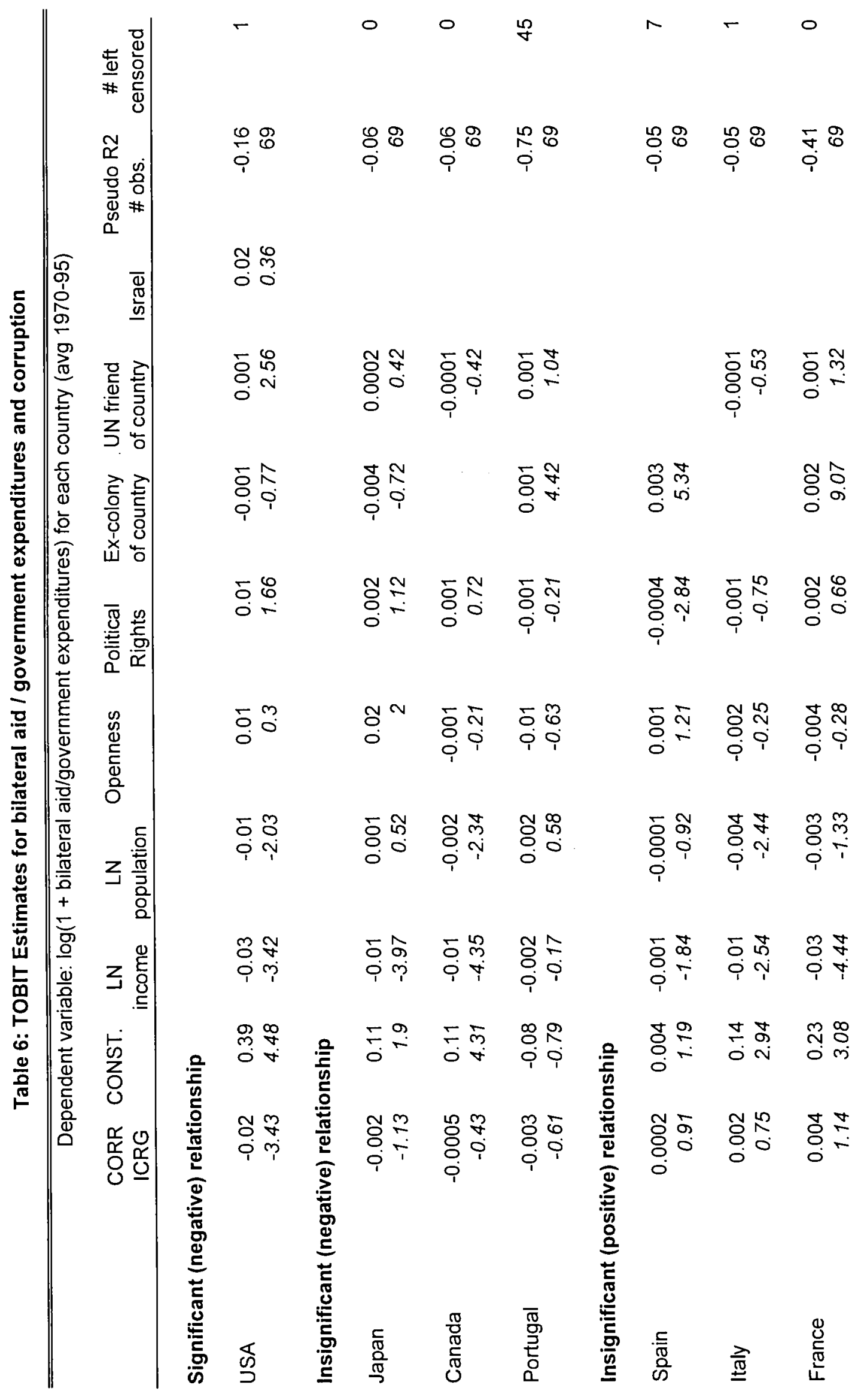




$$
\circ-\quad+\quad 0 \quad 0
$$

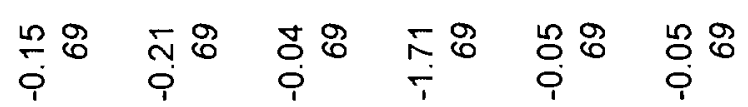

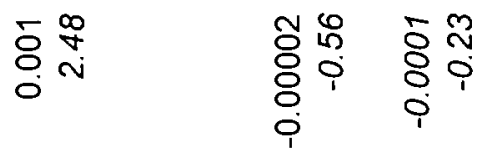

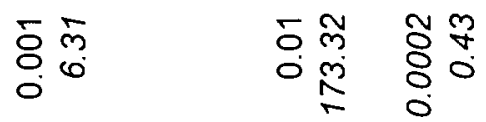

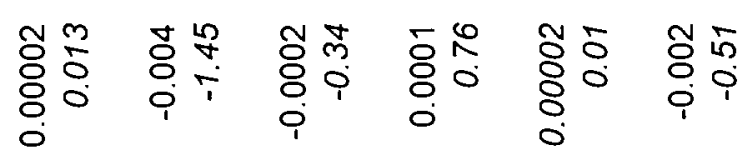

安

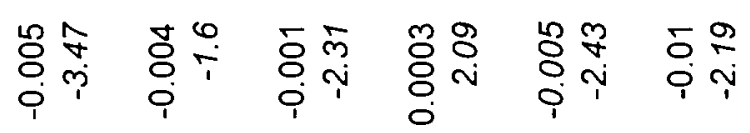

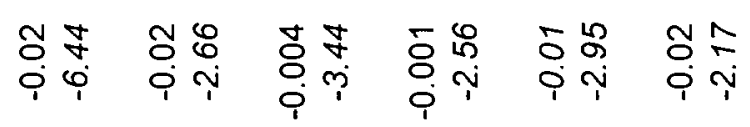

సิํㅆㄹ

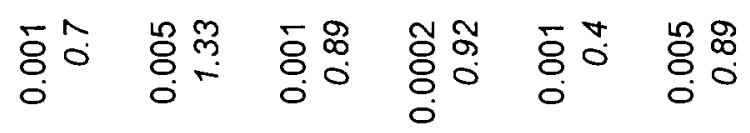

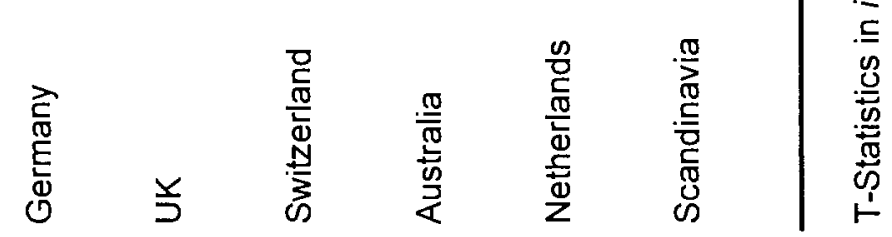




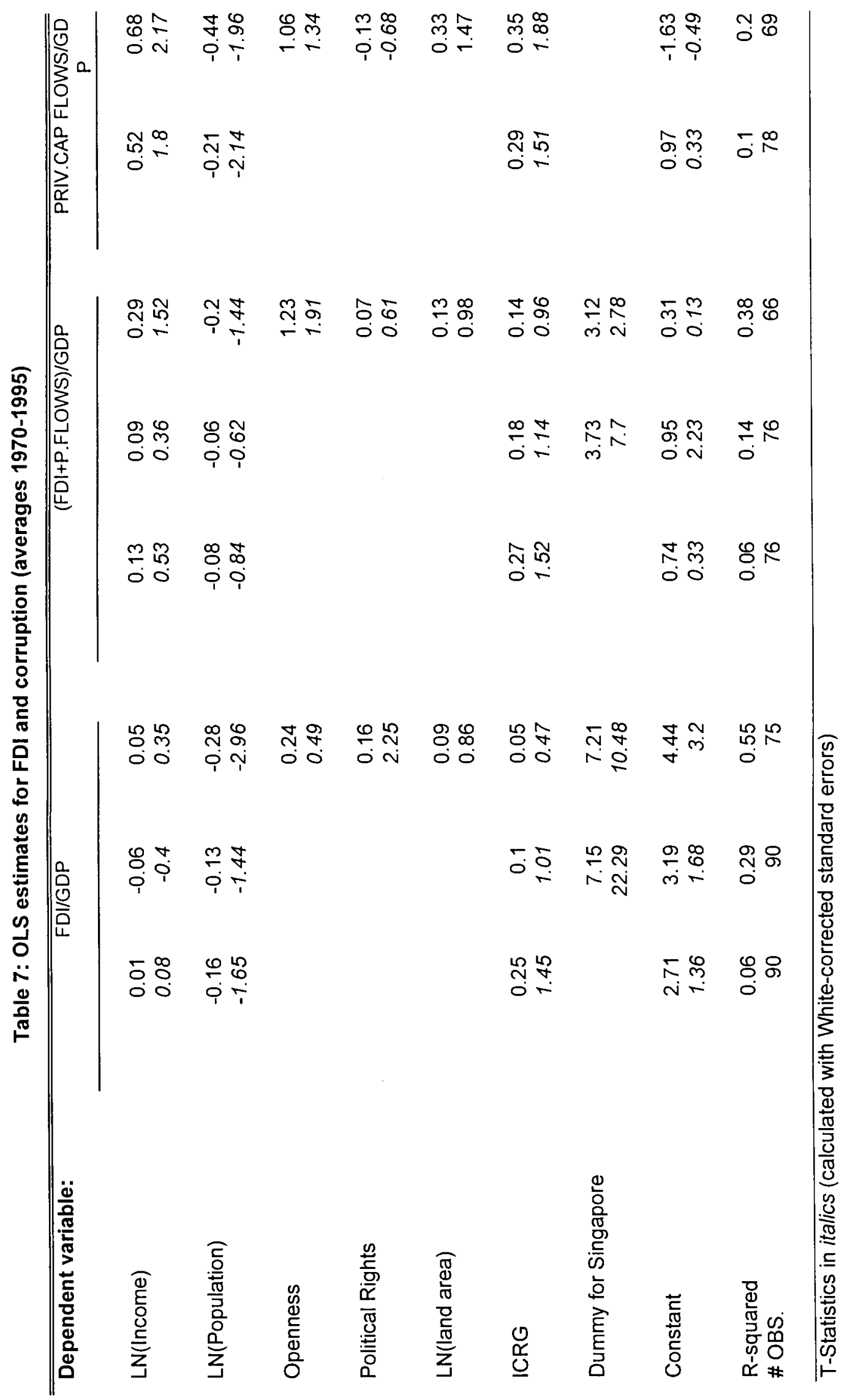




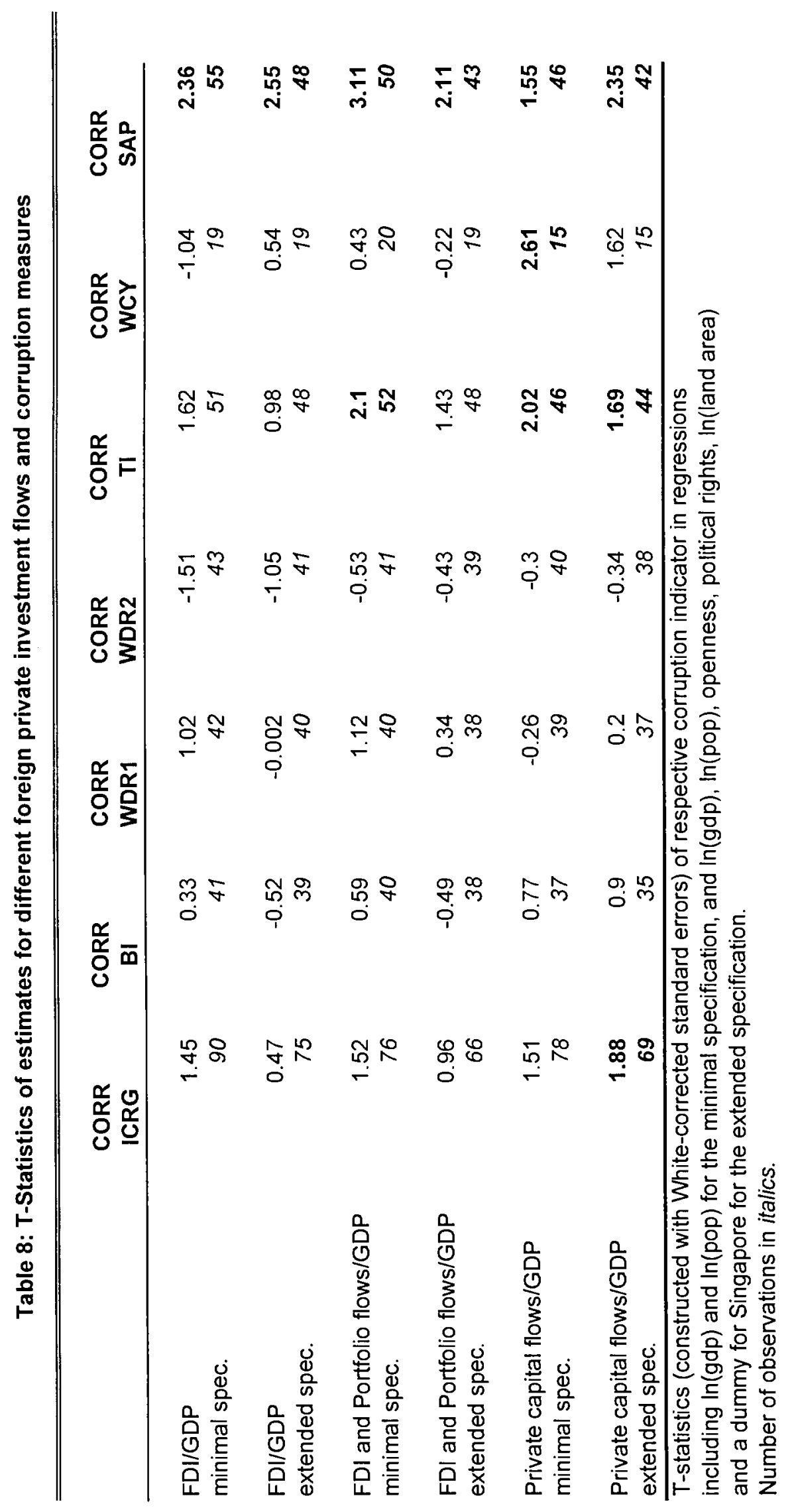




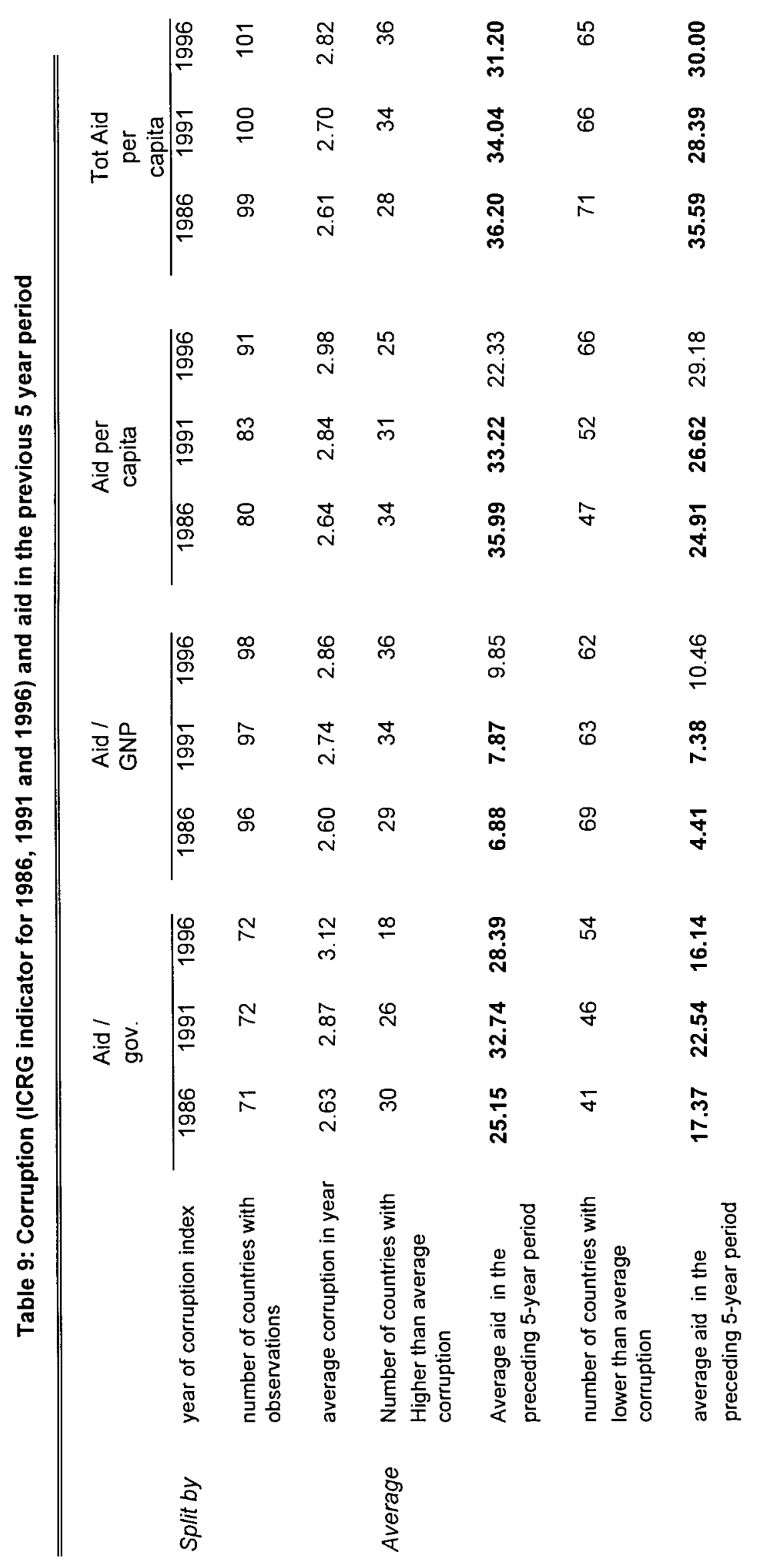




\begin{tabular}{|c|c|c|c|c|c|c|c|}
\hline $\bar{\Sigma}$ & $\begin{array}{l}\infty \\
\stackrel{0}{0} \\
\stackrel{0}{0}\end{array}$ & $\overline{5}$ & $\begin{array}{l}\infty \\
\infty \\
\infty \\
0\end{array}$ & i & 品 & i & $\frac{n}{m}$ \\
\hline is & 占 & is & $\stackrel{\circ}{\stackrel{ }{N}}$ & $\stackrel{\sim}{\sim}$ & $\stackrel{\sim}{\stackrel{+}{\sigma}}$ & $\stackrel{i}{ }$ & 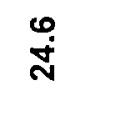 \\
\hline in & 命 & in & 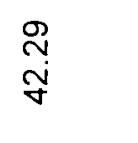 & $\stackrel{\text { N }}{ }$ & $\stackrel{\stackrel{9}{\dot{j}}}{\vec{p}}$ & $\stackrel{i}{i}$ & $\stackrel{\infty}{\stackrel{\sim}{0}}$ \\
\hline 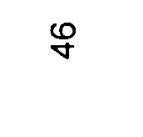 & 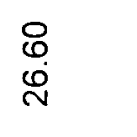 & \& & $\begin{array}{l}\tilde{N} \\
\stackrel{\sim}{\sim}\end{array}$ & $\stackrel{\infty}{\leftarrow}$ & $\begin{array}{l}\stackrel{\circ}{\infty} \\
\stackrel{\dot{\sim}}{N}\end{array}$ & $\stackrel{\infty}{-}$ & $\stackrel{\Delta}{\stackrel{N}{N}}$ \\
\hline $\mathcal{F}$ & 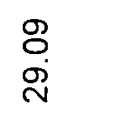 & F & $\begin{array}{l}\tilde{N} \\
\text { oj }\end{array}$ & $\stackrel{f}{ }$ & $\begin{array}{l}\tilde{G} \\
\stackrel{\tilde{d}}{\mathrm{~d}}\end{array}$ & $\stackrel{F}{ }$ & 总 \\
\hline q & 怘 & q & $\underset{\leftrightarrow}{\stackrel{\sim}{\oplus}}$ & $\stackrel{\circ}{\circ}$ & $\begin{array}{l}\mathbb{J} \\
d \\
d\end{array}$ & 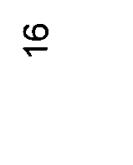 & $\stackrel{\substack{\infty \\
\infty}}{\sim}$ \\
\hline$g$ & 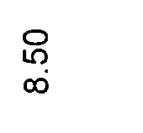 & g & $\underset{\sigma}{\sigma}$ & i & $\begin{array}{l}\text { ț } \\
\stackrel{0}{0}\end{array}$ & $\stackrel{i}{ }$ & $\stackrel{\circ}{\stackrel{\circ}{\circ}}$ \\
\hline g & $\stackrel{8}{\circ}$ & g & 吕 & $\stackrel{\rho}{\sim}$ & 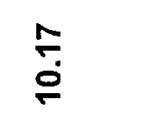 & $\stackrel{9}{\leftarrow}$ & $\stackrel{\infty}{\infty}$ \\
\hline$\stackrel{\infty}{\sigma}$ & $\stackrel{\mathscr{N}}{\mathscr{N}}$ & $\stackrel{\infty}{q}$ & 串 & $\stackrel{\rho}{\rho}$ & $\stackrel{R}{R}$ & $\stackrel{\mathscr{Q}}{\longrightarrow}$ & $\stackrel{\circ}{\leftrightarrow}$ \\
\hline$\stackrel{๗}{\infty}$ & $\underset{\grave{N}}{\bar{N}}$ & 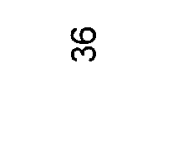 & 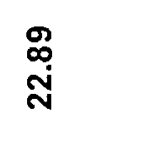 & $\stackrel{\forall}{\sim}$ & $\underset{\substack{\infty \\
\infty}}{\bar{\infty}}$ & $\stackrel{I}{ }$ & $\begin{array}{l}\hat{\omega} \\
\stackrel{\leftrightarrow}{N}\end{array}$ \\
\hline $\mathscr{\infty}$ & $\stackrel{\widetilde{\infty}}{\stackrel{\sim}{\sim}}$ & $\ddot{\infty}$ & $\stackrel{\vec{F}}{\stackrel{+}{*}}$ & $\stackrel{\nabla}{ }$ & $\begin{array}{l}\text { ợ } \\
\dot{g}\end{array}$ & $\stackrel{\nabla}{ }$ & $\begin{array}{l}\text { 。̆ } \\
\text { م. }\end{array}$ \\
\hline 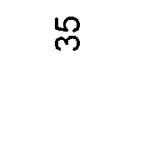 & 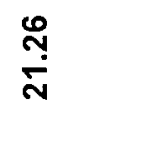 & ஜ & 莕 & $\stackrel{\nabla}{\square}$ & $\stackrel{\tilde{N}}{\stackrel{\tilde{m}}{\tilde{n}}}$ & $\stackrel{ \pm}{ \pm}$ & 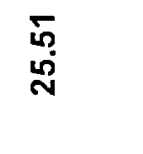 \\
\hline 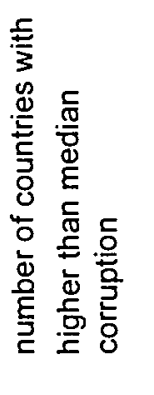 & 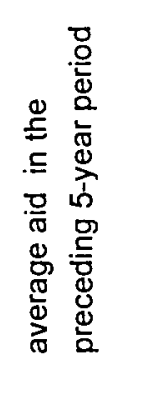 & 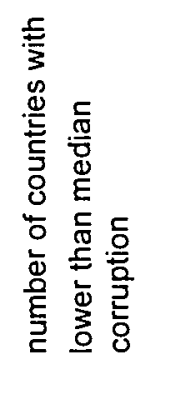 & 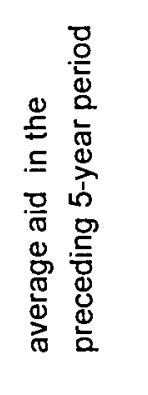 & 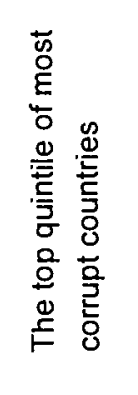 & 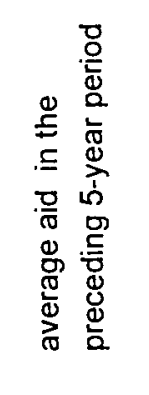 & 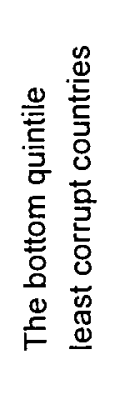 & 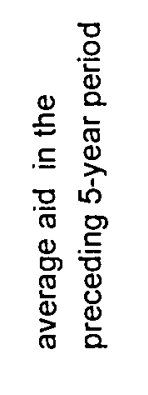 \\
\hline & & & & 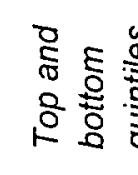 & & & \\
\hline
\end{tabular}


Table 10: Corruption (ICRG avg. 1990-95) and previous aid (avg. 1981-95)

\begin{tabular}{|c|c|c|c|c|c|}
\hline & & Aid/Gov & Aid / GNP & Total Aid pc & $\begin{array}{c}\text { Bilateral } \\
\text { Aid pc }\end{array}$ \\
\hline & Number of countries & 72 & 98 & 101 & 91 \\
\hline & Average Corruption & 2.96 & 2.72 & 2.68 & 2.83 \\
\hline \multirow[t]{4}{*}{ Average } & $\begin{array}{l}\text { Number of countries } \\
\text { with higher than } \\
\text { average corruption }\end{array}$ & 26 & 39 & 32 & 32 \\
\hline & Average aid & 30.75 & 8.27 & 31.89 & 27.89 \\
\hline & $\begin{array}{l}\text { number of countries } \\
\text { with lower than } \\
\text { average corruption }\end{array}$ & 46 & 59 & 69 & 66 \\
\hline & Average aid & 23.13 & 6.26 & 32.90 & 25.02 \\
\hline \multirow[t]{5}{*}{ Median } & $\begin{array}{l}\text { Countries with corruption } \\
\text { higher than median }\end{array}$ & 36 & 49 & 50.5 & 45.5 \\
\hline & Average aid & 25.02 & 7.47 & 30.54 & 27.20 \\
\hline & number of countries with & & & & \\
\hline & lower than median & 36 & 49 & 50.5 & 45.5 \\
\hline & Average aid & 18.51 & 6.63 & 32.26 & 24.53 \\
\hline \multirow{4}{*}{$\begin{array}{l}\text { Top and } \\
\text { bottom } \\
\text { quintiles }\end{array}$} & $\begin{array}{l}\text { The top quintile most } \\
\text { corrupt countries }\end{array}$ & 14.4 & 19.6 & 20.2 & 18.2 \\
\hline & Average aid & 33.32 & 11.42 & 31.92 & 29.86 \\
\hline & $\begin{array}{l}\text { The bottom quintile } \\
\text { Least corrupt countries }\end{array}$ & 14.4 & 19.60 & 20.2 & 18.2 \\
\hline & Average aid & 20.59 & 6.06 & 21.01 & 19.45 \\
\hline
\end{tabular}

Bold numbers indicate that more corrupt countries had received higher aid. 
Figure 1:

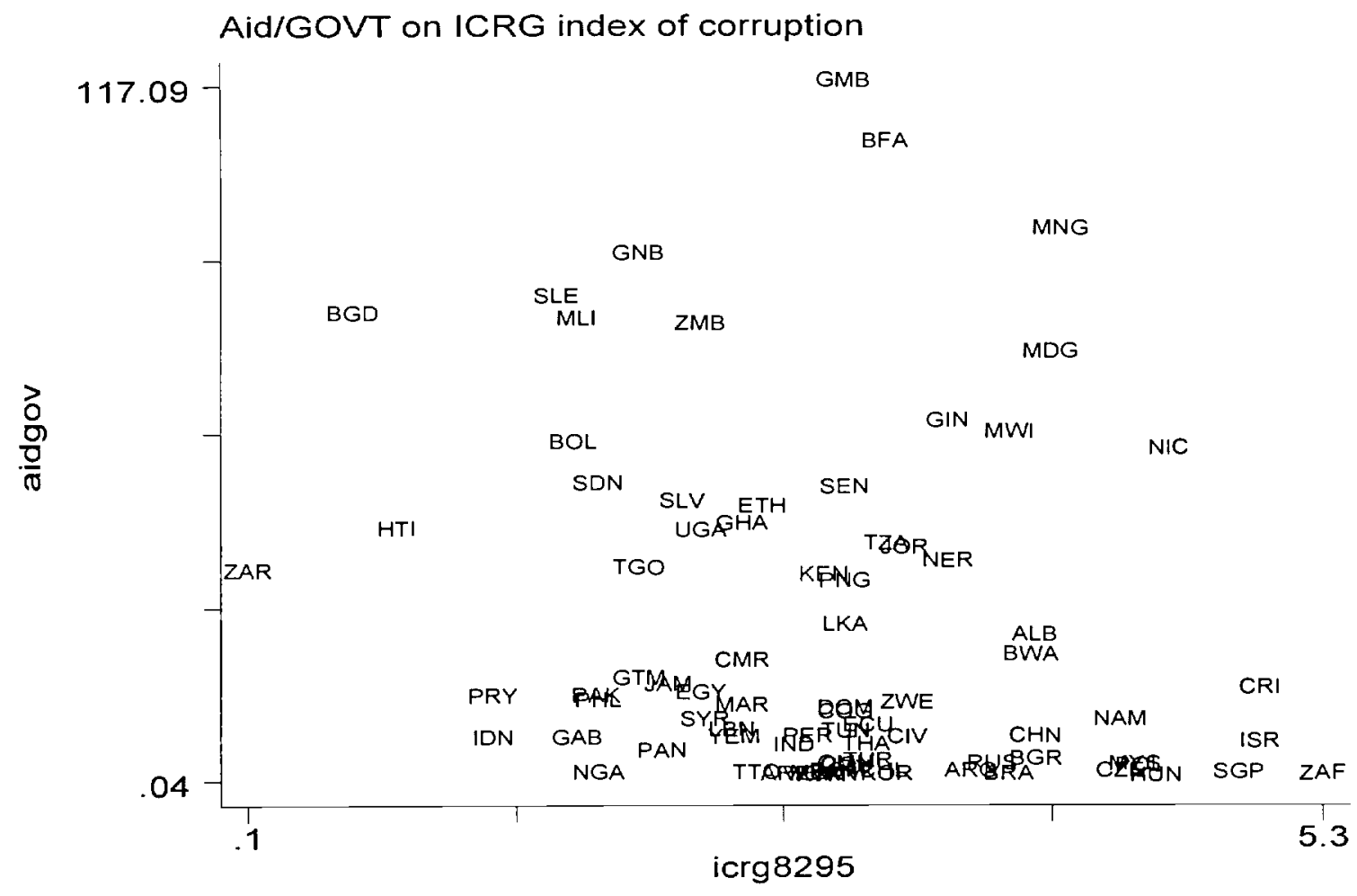


Figure 2:

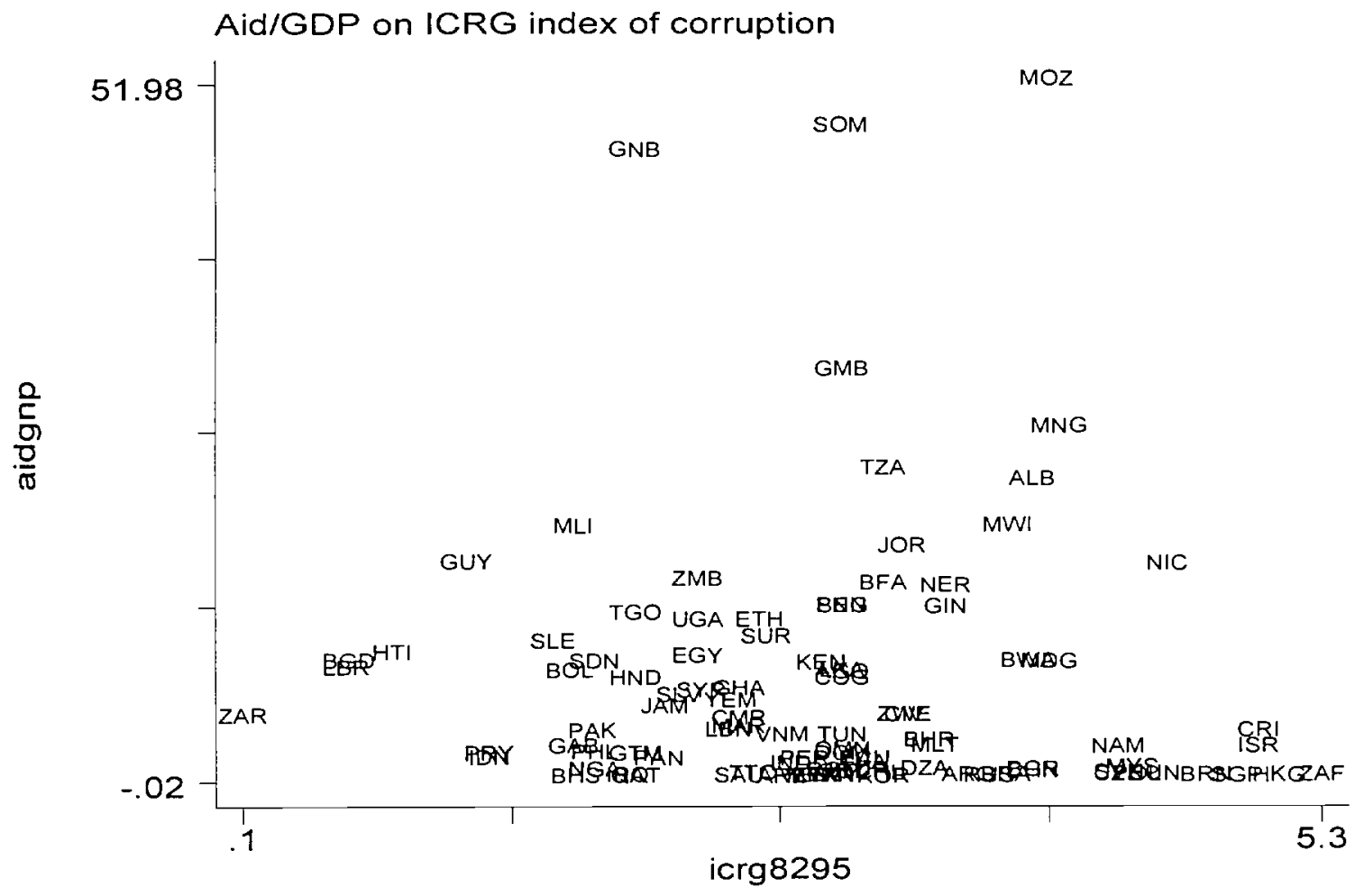


Figure 3:

Aid per capita on ICRG index of corruption

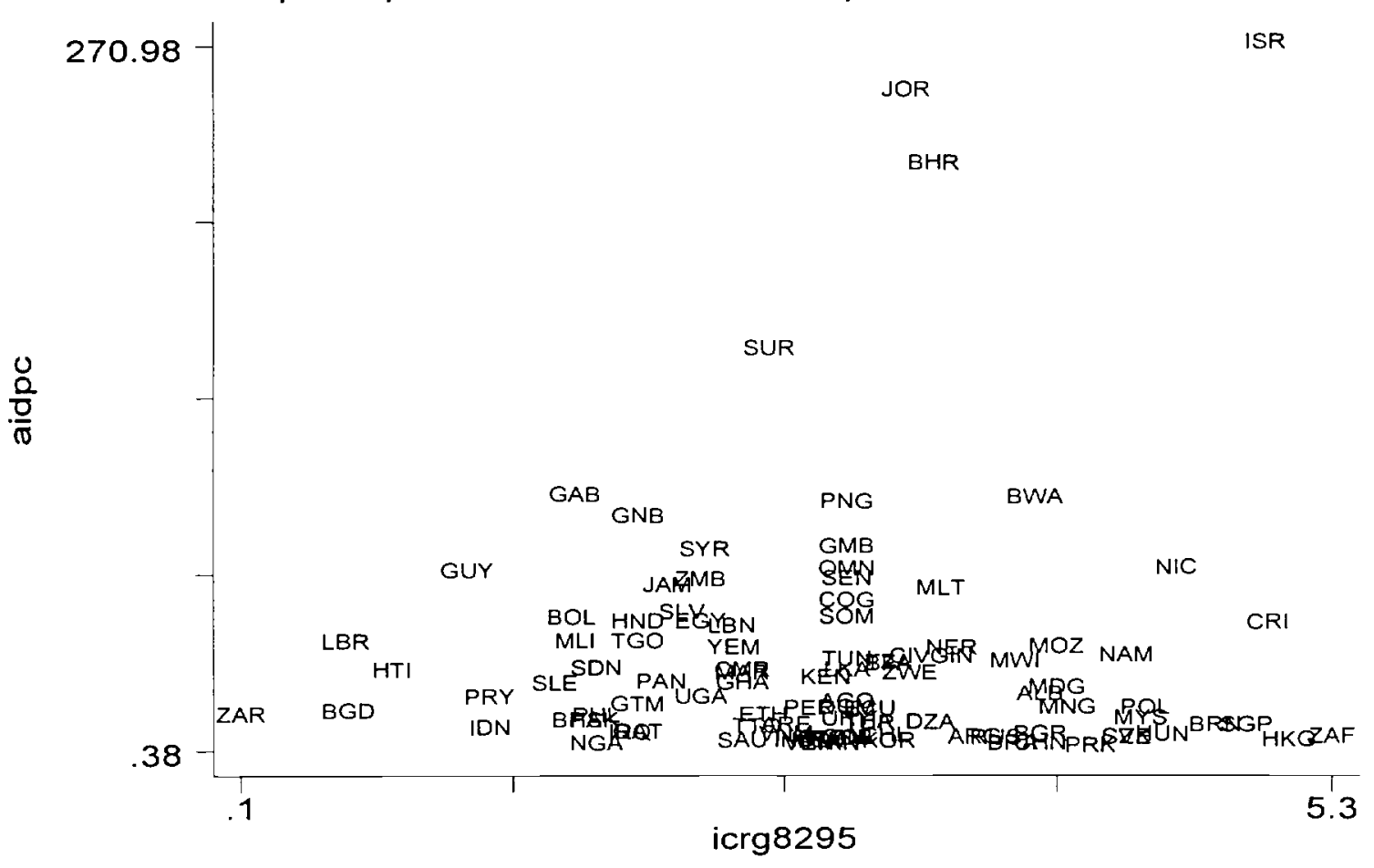


Figure 4: USA residuals of aid/government expenditures on corruption

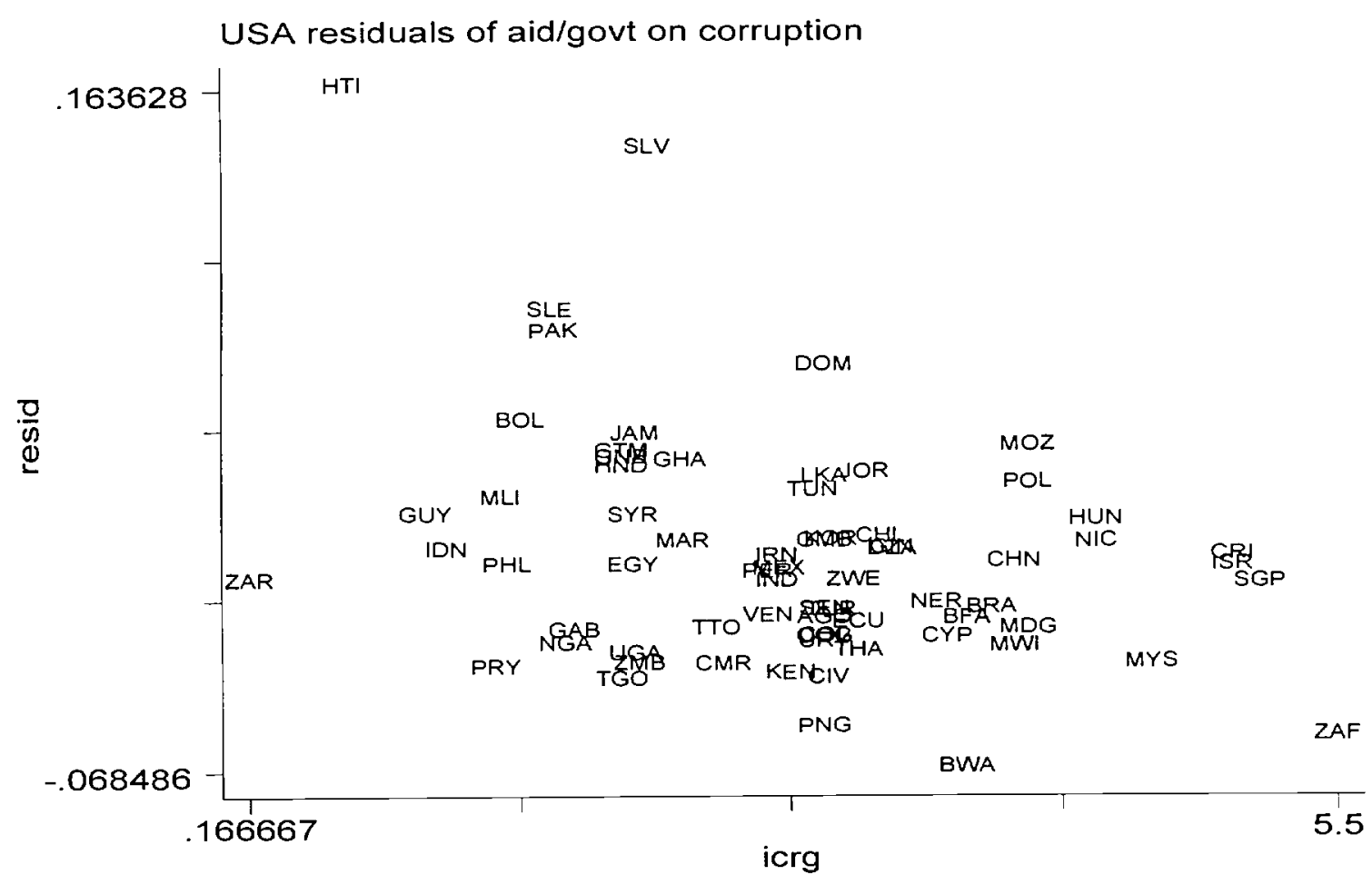


Figure 4a): USA residuals of aid per capita on corruption

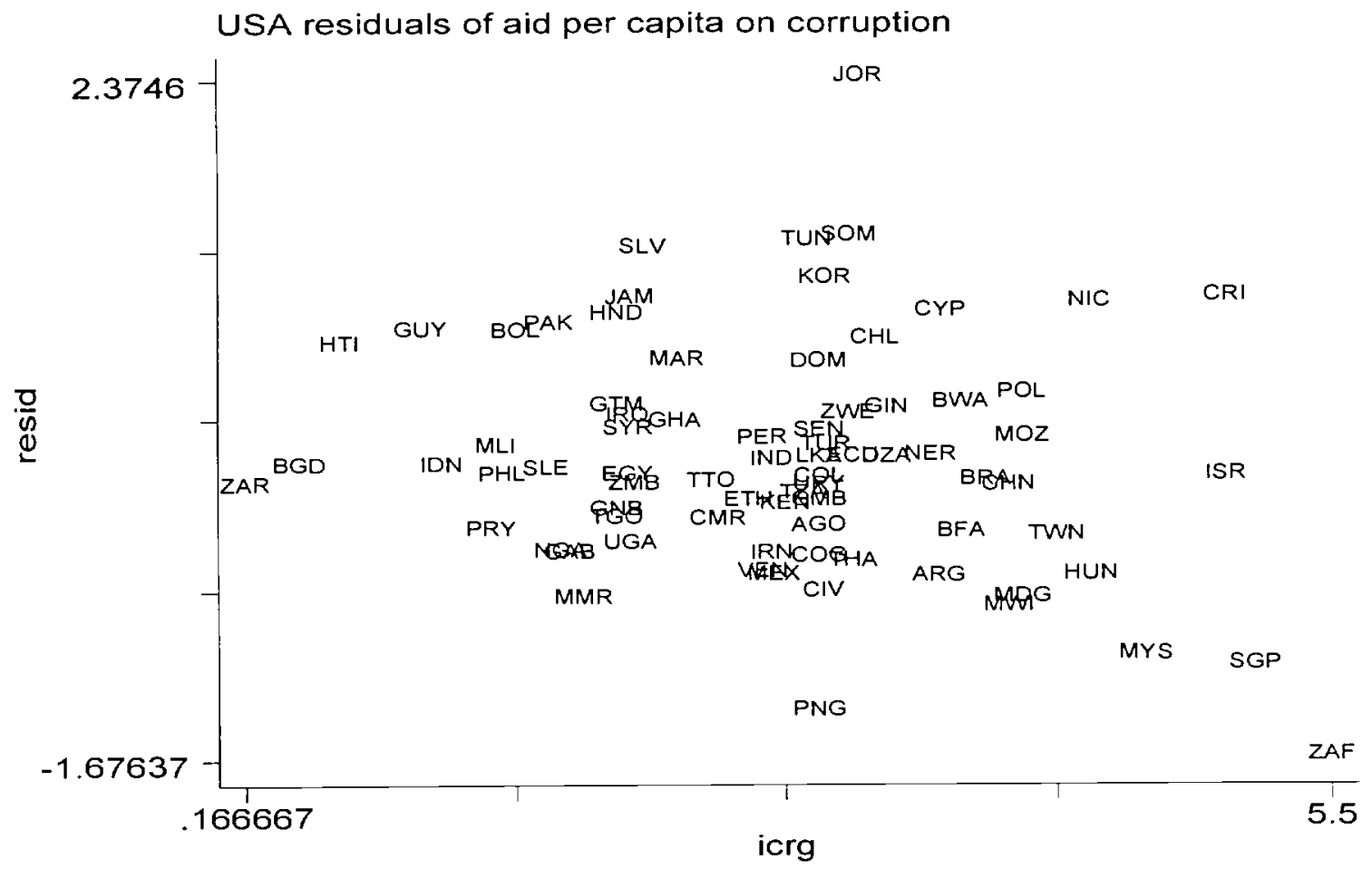

